\title{
DETERMINATION OF COMPLEXABLE METALS \\ BY CHELOMETRIC TITRATION
}

\author{
Barry H. Nicholson
}

\author{
Analytical Laboratories \\ Engineering Department \\ Production and Waste Management Division
}

\footnotetext{
June 1977

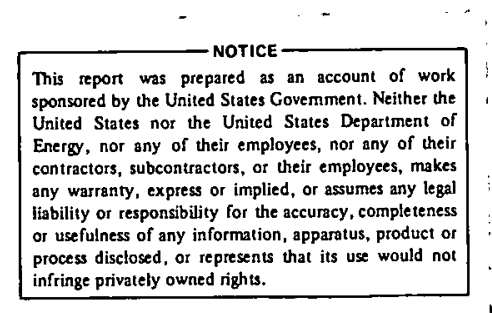

Atlantic Richfield Hanford Company

Richland, Washington 99352
} 


\section{DISCLAIMER}

This report was prepared as an account of work sponsored by an agency of the United States Government. Neither the United States Government nor any agency Thereof, nor any of their employees, makes any warranty, express or implied, or assumes any legal liability or responsibility for the accuracy, completeness, or usefulness of any information, apparatus, product, or process disclosed, or represents that its use would not infringe privately owned rights. Reference herein to any specific commercial product, process, or service by trade name, trademark, manufacturer, or otherwise does not necessarily constitute or imply its endorsement, recommendation, or favoring by the United States Government or any agency thereof. The views and opinions of authors expressed herein do not necessarily state or reflect those of the United States Government or any agency thereof. 


\section{DISCLAIMER}

Portions of this document may be illegible in electronic image products. Images are produced from the best available original document. 


\section{TABLE OF CONTENTS}

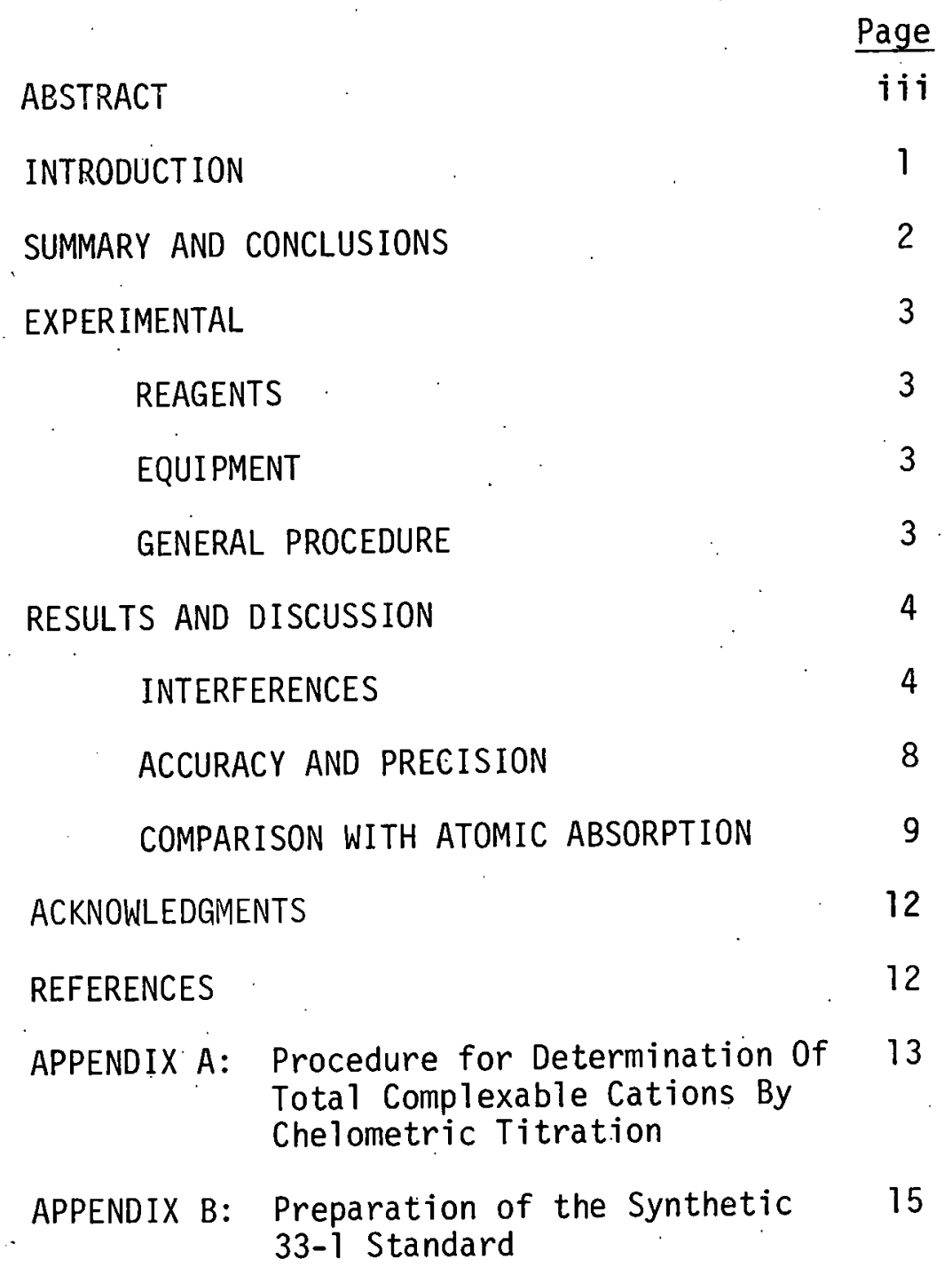


UNCLASSIFIED

ARH-ST-138

ii i

ABSTRACT

A rapid, simple method for the determination of total complexable metal ions ( $\mathrm{Fe}^{3+}, \mathrm{Al}^{3+}, \mathrm{Mn}^{2+}, \mathrm{Ni}^{2+}, \mathrm{Co}^{2+}, \mathrm{Pb}^{2+}$, and Rare Earths) in feed to the Hanford strontium recovery process has been developed. The method consists of complexing the metal ions with EDTA and titrating the excess with copper (II) ion. Pyrocatechol violet is used as a colorimetric end point indicator.

Samples of actual process feed were analyzed and the results compared very favorably with results by atomic absorption. Use of a synthetic feed standard showed an average accuracy of $99.7 \%$ and a relative precision of 土. $1.9 \%$ ( $95 \%$ C.L.).

Interference studies run on the method show that oxalate and phosphate interfere above mole ratios of 0.1 and 0.3 , respectively (anion : total complexable cations). Of the complexable metal ions commonly encountered in this feed (specifically excluding alkali and alkaline-earth metals), the only complexable ion not determinable by this method is $\mathrm{Cr}$ (III). 
ARH-ST-1 138

\section{IITTRODUCTION}

Nuclear fuel reprocessing plants, such as the Purex Plant on the Hanford reservation, generated large volumes of liquid waste containing very high levels of fission products. As part of the current Hanford Waste Management program, $(1,2)$ the high activity of this liquid waste, some of it self-boiling, must be, reduced or removed to reduce the heat load of the storage tanks. Most of the fission products present (e.g., ${ }^{95} \mathrm{ZrNb}$, ${ }^{103} \mathrm{Ru},{ }^{106} \mathrm{RuRh},{ }^{144} \mathrm{CePr}$, etc.) are relatively short-1ived (one year or less), so the concentrations of these radionuclides are reduced by simply. allowing the waste to decay for a few years. However, the quantities of ${ }^{90} \mathrm{Sr}$. and ${ }^{137} \mathrm{Cs}$ are not significantly reduced in this time period, owing to their relatively long half-lives (28.8 and 30.2 years, respectively). Consequently, the bulk of these isotopes is removed at the waste Fractionization Processing Plant (B-Plant).

Most of the ${ }^{90} \mathrm{Sr}$ is removed by solvent extraction. The feed, which is currently PAS (Purex Acidified Sludge) is complexed with a mixture of ethylenediaminetetraacetic acid (EDTA), hydroxyethylethylenediaminetri- . : acetic acid (HEDTA), and sodium citrate, and the $\mathrm{pH}$ is adjusted to 5.0 with sodium carbonate. This treated feed is then contacted with an organic solution of bis(2-ethylhexyl)phosphoric acid (HDEHP) and tributyl phosphate (TBP) in normal paraffin hydrocarbon (NPH).*

The total content of metal ions complexable at pH 5 must be known in order that the proper amount of complexant may be added. Insufficient complexant will cause some of these metals to extract, loading the solvent and suppressing extraction of strontium. Too much complexant is wasteful and can lead to decreased extraction of strontium through complex formation. (2) Therefore, a method is needed that will determine the concentrations of all the metal ions normally complexable at $\mathrm{pH} 5$ with the complexants used in the process. Ideally, the method would be rapid, simple, and determine all the metal ions simultaneously.

There have been a number of methods used in the past for determining complexable cations. Probably the simplest was titration with standard $\mathrm{NaOH}$, solution, since the cations of interest are hydrolyzed in aqueous solution. Two titrations were done, with an excess of oxalate ion added to one titration. The difference between the results of these two titrations was the acid due to the hydrolysis of the cations. The chief disadvantage of this method is that not all the cations are in the same valence state, so each species consumes relatively different amounts of base. Furthermore, not all the ions complexable with EDTA are complexable with oxalate.

*A mixture of straight-chain alkanes, usually from 9 to 14 carbons in length. 


\section{INTRODUCTION (Contd)}

The other method which was used for a number of years was atomic absorp. tion, in which the major complexable metals ( $A 1, \mathrm{Fe}, \mathrm{Mn}$ ) were determined. This method usually gave reliable results; however, some were often erratic, presumbly because of matrix effects or poor technique, but otherwise unexplainable. Additionally, the turnaround time was very siow, sometimes as long as five shifts ( 240 hours). Moreover, because of the high radioactivity of these samples (usually upwards of l Curie/liter $90 \mathrm{Sr})$, personnel exposure was a problem.

Since EDTA is one of the complexants used in the process to complex the undesirable metals, a method was sought that utilized EDTA. Kritz ${ }^{3}$ had used a back-titration method for determining $A l$ and $\mathrm{Fe}$ in glass, and I found that this method could be expanded to include $\mathrm{Mn}, \mathrm{Co}, \mathrm{Pb}$, and a number of other metals, as well as Al and Fe.

\section{SUMMARY AND CONCLUSIONS}

A method has been developed for the determination of total complexable cations in PAS feed solutions. An accuracy of 99.7 percent was observed on synthetic standard feed solutions, and the precision was $\pm 1.9 \%$ at the 95\% confidence level.

Results on actual process samples appear to agree quite well with those by atomic absorption $(A A)$, and these results generally appear less erratic than the $A A$ results.

The method is rapid and simple and appears well suited to the anilysis of these feed solutions, as it determines all the complexable metal ions except $\mathrm{Cr}$ (III) simultaneously. In the present feed, $\mathrm{Cr}$ (III) is usually less than $1 \%$ of the total complexable cations and can hence be neglected without causing a significant problem or bias in the determination.

By and large, it is felt that this titrimetric method is capable of giving more reliable results than $A A$ on strontium recovery feed samples to B-Plant. Additionally, turnaround time and radiation exposure are greatly reduced. 
UNCLASSIFIED

ARH-ST -138

3

EXPERIMENTAL

\section{REAGENTS}

1. Ethyl enediaminetetraacetic Acid (EDTA), $0.1000 \pm 0.01 \mathrm{M}$

Dissolve 37.2 grams of the disodium salt dihydrate in deionized water and dilute to one liter. Standardize to $0.0001 \mathrm{M}$ by an accepted method (e.g., Calcium with Eriochrome Black T). Store in a polyethylene bottle.

2. Pyridine; reagent grade

3. Pyrocatechol Violet, $0.1 \%$

Dissolve 0.1 gram of pyrocatechol violet in deionized water and dilute to $100 \mathrm{~m} 1$.

4. Standard Copper Solution, $0.1000 \pm 0.0100 \underline{M}$

Weigh out 6.35 grams of copper (minimum purity 99.9\%) to 0.0001 gram. Dissolve in a minimum amount of $6 \mathrm{M}$ nitric acid. When dissolution is complete, cool and dilute to one liter with deionized water. This is a primary standard and is calculated as follows:

$$
\mathrm{Cu}^{2+} \text { concentration }(\underline{M})=\frac{\text { weight of } \mathrm{Cu} \text { (grams) }}{63.54}
$$

\section{EQUIPMENT}

1. Magnetic' stirrer and glass-covered stir bars.

2. $\mathrm{pH}$ meter.

3. Manostat or ultramicroburet - calibrated to read $2 \mu 1$ or less.

\section{GENERAL PROCEDURE}

Pipet sample, containing .05 to .08 millimole of complexable cations, into about $10 \mathrm{ml}$ of deionized water in a glass vial. If necessary, adjust the $\mathrm{pH}$ to between 1 and 3 with $0.1 \mathrm{M} \mathrm{NaOH}$ or $\mathrm{HNO}_{3}$. While stirring, add exactly $1000 \mu 1$ of standardized $0.10 \mathrm{M}$ EDTA, $1 \mathrm{ml}$ of pyridine, and 2 drops indicator. Titrate with standard $0.10 \mathrm{M}$ copper(II) nitrate solution until the : color changes from yellow to a dark bluish-green. The color change is complete over about a $5 \mu 1$ addition of titrant when the stated.concentrations of all reagents are used. 


\section{RESULTS AND DISCUSSION}

Determination of metals by chelometric titration with EDTA is a relatively old method, often subject to numerous interferences when one particular cation is desired in the presence of others. However, the problem in this case was to determine all the complexable metal ions in solution at once. The method used is a conventional back-titration type of determination with a colorimetric end point. The color of the indicator used, pyrocatechol violet, is $\mathrm{pH}$ dependent and is normally yellow at $\mathrm{pH} 5-6$. It forms a bright blue fomplex with $\mathrm{Cu}(\mathrm{II})$, as well as a number of other metals, above $\mathrm{pH} 5 \mathrm{r}^{1}$. The indicator complexes of all these metals are generally weaker than the corresponding EDTA complexes, so the metal indicator complex will form in solution with only those cations not complexed with EDTA.

After sample addition and the initial $\mathrm{pH}$ adjustment, a known excess of standard EDTA is added, which complexes the metal ions according to the general reaction:

$$
\mathrm{M}^{\mathrm{n+}}+\mathrm{H}_{2} \mathrm{Y2}^{-} \rightarrow \mathrm{MY}^{\mathrm{n}-4}+2 \mathrm{H}^{+}
$$

The $\mathrm{pH}$ is then raised to about 5-6 by addition of pyridine. The exact reason that Kritz chose pyridine is not known, but a possible explanation could be that it is completely miscible with water and is a very weak base $\left(K_{b}=1.7 \times 10^{-9}\right)$ and could therefore provide good buffering action at a near-neutral $\mathrm{pH}$.

After the $\mathrm{pH}$ adjustment, indicator is added and the remaining free EDTA is titrated with copper (II) ion:

$$
\mathrm{Cu}^{2}+\mathrm{H}_{2} \mathrm{Y}^{2-}+2 \mathrm{H}^{+}+\mathrm{CuY}^{2-}
$$

When all the excess free EDTA is complexed, additional copper added forms the deep blue indicator complex, and this color change is taken as the end point.

\section{INTERFERENCES}

As this was a specialized method developed for a limited variety of cations, only the ions likely to be encountered in B Plant feed solutions were studied. These included nine cations (Table I) and five anions (Table II).

In the cation studies, the indicated amounts of each cation (as the chloride or nitrate) were added, and the solution was analyzed according to the detailed procedure given in Appendix A. 


\section{TABLE I}

DETERMINATION OF VARIOUS CATIONS BY CHELOMETRIC TITRATION (APPENDIX A)

\begin{tabular}{|c|c|c|c|c|c|c|c|c|c|}
\hline \multirow{2}{*}{$\begin{array}{l}\text { Run } \\
\text { No. }\end{array}$} & \multirow{2}{*}{$\begin{array}{l}\text { No. of } \\
\text { Trials }\end{array}$} & \multicolumn{4}{|c|}{ Micromoles Added: } & \multicolumn{2}{|c|}{ Total $\mu$ Moles: } & \multirow{2}{*}{$\begin{array}{c}\% \\
\text { Rec. }\end{array}$} & \\
\hline & & A] & $\mathrm{Fe}$ & $\mathrm{Mn}$ & Other & Added & Found & & \\
\hline 1 & 3 & 25 & 25 & 0 & 0 & 50 & 49.9 & 99.9 & \\
\hline 2 & 2 & 25 & 25 & 10 & 0 & 60 & 59.8 & 99.0 & \\
\hline 3 & 2 & 25 & 25 & 0 & $\mathrm{Mg}-10$ & 60 & 50.2 & 84.7 & \\
\hline 4 & 2 & $2 n$ & 20 & 10 & 0 & 50 & 49.8 & 99.6 & \\
\hline 5 & 2 & 20 & 20 & 10 & $\mathrm{Cr}-10$ & 60 & 49.7 & $82.9^{a}$ & \\
\hline 6 & 2 & 20 & 20 & 10 & $60-10$ & 60 & 59.8 & 99.7 & \\
\hline 7 & 2 & 20 & 20 & 10 & $\mathrm{Ni}-10$ & 60 & 59.2 & 98.7 & \\
\hline 8 & 2 & 20 & 20 & 10 & $\mathrm{~Pb}-10$ & 60 & 59.8 & 99.7 & \\
\hline 9 & 2 & 20 & 20 & 10 & $R E^{b}-6.25$ & 56.25 & 55.9 & 99.4 & \\
\hline
\end{tabular}

aprecipitate formed upon addition of pyridine.

$\mathrm{b}_{\mathrm{RE}}$ - Mixture of four Tanthanides (Sm, Eu, Gd, Dy). 
For the anion interference studies, a $100 \mu 1$ of aliquot of Synthetic B-Plant Feed Standard (Table III) was used and the indicated amount of anion added. Anions used were solutions of either the sodium or potassium salts. As in the cation studies, the procedure given in Appendix A was used.

TABLE II

ANION INTERFERENCE STUDIES

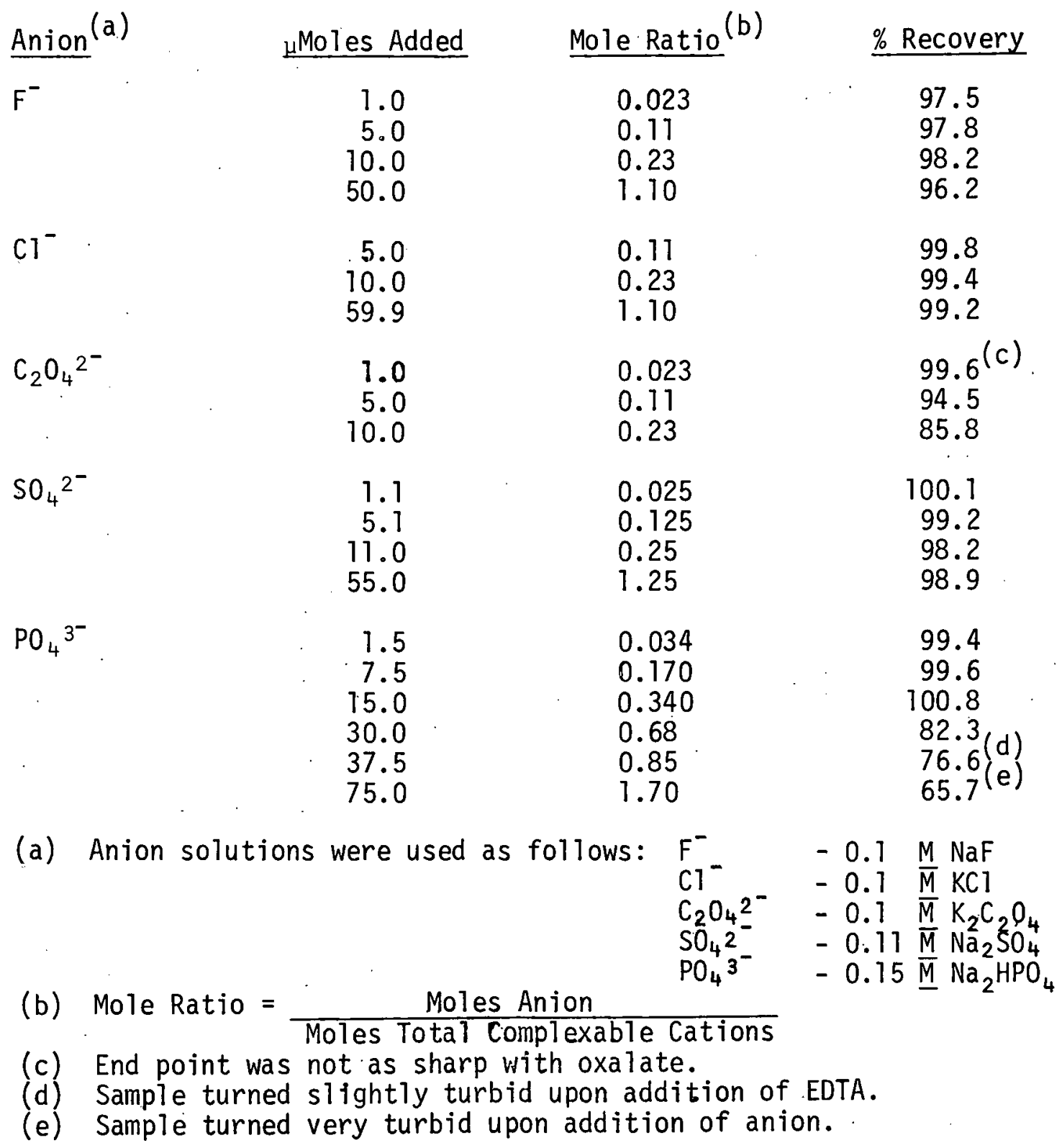


TABLE III

\section{SYNTHETIC FEED COMPOSITION}

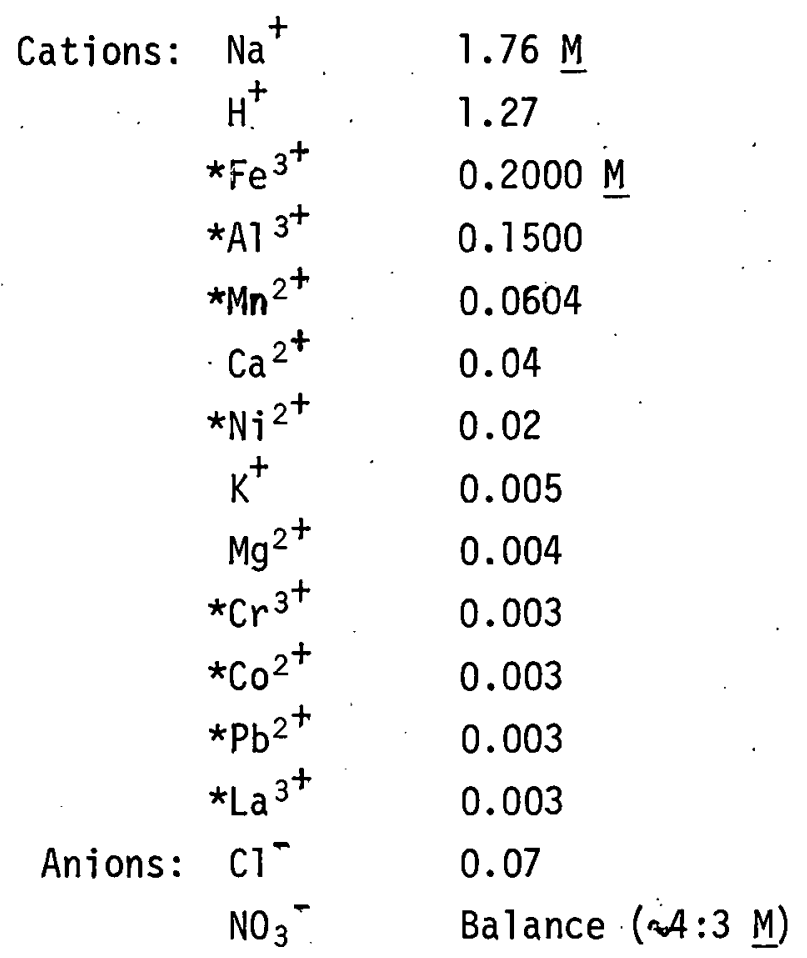

*Calculated Concentration of Total Complexable Cations $(\mathrm{TCC})=0.4424 \underline{\mathrm{M}}$

From Table I, you see that the only cation considered "complexable" which is not determinable by this method is $\operatorname{Cr}$ (III). Other cations not included in this study may, of course, also fail to be complexed. (Alkali and alkaline-earth metal ions are not normally complexed by EDTA at $\mathrm{pH}<9-10$.)

According to Welcher (5), Cr(III) forms a complex with EDTA only after boiling the solution for 15 minutes, so the $\mathrm{Cr}$ (III) complex would not form under the conditions used in this method.

of the anions studied, (Table II), you can see that phosphate $\left(\mathrm{PO}_{4}^{3}\right.$ ) and oxalate $\left(\mathrm{C}_{2} \mathrm{O}_{4}^{-}\right)$are the only anions which interfere when present in significant amounts. I infer that nitrate does not interfere, as it is the major anion present and so the anion:TCC ratio is very large $(\sim 10: 1)$,

Since determination of cations by this technique is based on complexation with EDTA, cations already complexed by EDTA or some other strong chelating agent in the original sample will not be determined. 


\section{ACCURACY AND PRECISION}

Repeated runs (Table IV) with the synthetic feed standard show an average accuracy of $99.7 \%$ and a relative precision of $\pm 1.9 \%$ at the $95 \%$ confidence level.

\section{TABLE IV}

DETERMINATION OF ACCURACY AND PRECISION CAPABILITIES ${ }^{a}$

\begin{tabular}{ccc} 
Trial No. & Result (M) & \% Recovery \\
\hline 1 & 0.449 & 101.5 \\
2 & 0.441 & 99.6 \\
3 & 0.442 & 99.8 \\
4 & 0.429 & 97.1 \\
5 & 0.440 & 99.6 \\
6 & 0.444 & 100.3 \\
7 & 0.438 & 99.0 \\
8 & 0.446 & 100.8 \\
9 & 0.440 & 99.4 \\
andard Value $=0.4424$ & \\
\end{tabular}


COMPARISON WITH ATOMIC ABSORPTION

Prior to development of this titrimetric method, atomic absorption (AA) was used for analysis of the three primary metallic constituents in the PAS B-Plant feed $(A 1, \mathrm{Fe}$, and $\mathrm{Mn})$. However, $A A$ sometimes gave erratic, unreliable results, possibly due to poor technique, matrix problems, or excessive spike corrections.

A series of actual feed samples from the routine sample point, tank 33-1, were run by both methods and the results compared (Table V).

\section{TABLE V}

ANALYTICAL RESULTS OF TK-33-1 SAMPLES

\begin{tabular}{|c|c|c|c|c|}
\hline $\begin{array}{l}\text { Sample } \\
\text { Number }\end{array}$ & $\begin{array}{l}\text { Number } \\
\text { of Trials }\end{array}$ & $\begin{array}{l}\text { Results: (M) } \\
\text { This Method }\end{array}$ & $\underline{A A}$ & $\begin{array}{c}\text { Percent Diff. } \\
\text { (This Method Vs. AA) }\end{array}$ \\
\hline$i$ & 3 & 0.516 & 0.510 & $+1.1 \%$ \\
\hline 2 & 2 & 0.571 & 0.553 & +3.2 \\
\hline 3 & 2 & 0.571 & 0.564 & +1.2 \\
\hline 4 & 2 & 0.668 & 0.665 & +0.5 \\
\hline 5 & 2 & 0.673 & 0.703 & -4.3 \\
\hline 6 & 2 & 0.662 & 0.698 & -5.2 \\
\hline
\end{tabular}

The titrimetric results compare quite favorably with the AA results, and in fact should be biased slightly. higher, since there are other complexable cations in the feed besides $\mathrm{Al}^{3}+, \mathrm{Fe}^{3+}$, and $\mathrm{Mn}^{2}+$.

As a further check, 25 samples were analyzed by shift personnel over a period of about one month using both methods, and the results were again compared (Table VI and Figure 1). 
UNCLASSIFIED

ARH-ST - 138

10

TABLE VI

RESULTS OF LONG-TERM SAMPLE STUDY

\begin{tabular}{|c|c|c|c|}
\hline Sample & & $\mathrm{ts}^{\mathrm{a}}$ & Percent Dif \\
\hline No. & TCC & AA & (TCC Vs. AA \\
\hline 1 & .415 & .395 & +5.7 \\
\hline 2 & .474 & .518 & -8.5 \\
\hline 3 & .534 & .507 & +5.3 \\
\hline 4 & .579 & .634 & -8.7 \\
\hline 5 & .496 & .449 & +10.5 \\
\hline 6 & $.611_{b}$ & .551 & +10.9 \\
\hline 7 & I.S.b & .634 & $\cdots$ \\
\hline 8 & .648 & .563 & +15.1 \\
\hline 9 & .657 & .703 & -6.5 \\
\hline $10^{\mathrm{C}}$ & & .663 & +2.6 \\
\hline $\begin{array}{l}11 \\
12\end{array}$ & .679 & $\begin{array}{l}.711 \\
666\end{array}$ & $\begin{array}{r}-4.5 \\
+2.2\end{array}$ \\
\hline 13 & .676 & .586 & +15.4 \\
\hline 14 & .622 & $.645 d$ & -3.6 \\
\hline 15 & .680 & $.424 \mathrm{~d}$ & +60 \\
\hline 16 & .673 & $.201^{a}$ & +235 \\
\hline 17 & .638 & .698 & -8.6 \\
\hline 18 & .621 & $.494 \mathrm{~d}$ & +25.7 \\
\hline 19 & .667 & $1.072^{\mathrm{a}}$ & -37.8 \\
\hline 20 & .672 & .638 & +5.3 \\
\hline 21 & .551 & .444 & +24.1 \\
\hline 22 & .614 & .537 & +14.3 \\
\hline 23 & .568 & .676 & -16.0 \\
\hline 24 & .632. & . 216 & +22.0 \\
\hline 25 & N.D. ${ }^{e}$ & .608 & $-\cdots$ \\
\hline
\end{tabular}

a Average Standard Recovery $(T C C)=101.2 \pm 6.0 \%$ on 23 determinations ( $95 \%$ C.L.)

bI.S. = Insufficient Sample. First titration of this sample turned green and a precipitate formed upon addition of indicator. There wasn't enough sample to rerun.

CSamples 10,11, and 12 are from same batch of feed, taken at different times.

dQuestionable AA Results: 15 - Low Fe and Mn

16 - Low Al

19 - High Al (43\% spike recovery)

$\mathrm{e}_{\mathrm{N} . \mathrm{S} .}=$ Not Determinable. This sample contained $\sim 25-50 \%$ solids, making the dilution dark enough to mask any color change.

As seen from Figure 1, the results by this method (TCC) follow a much smoother variation and appear less erratic than some of the AA results, noting especially samples 16 and 19. 


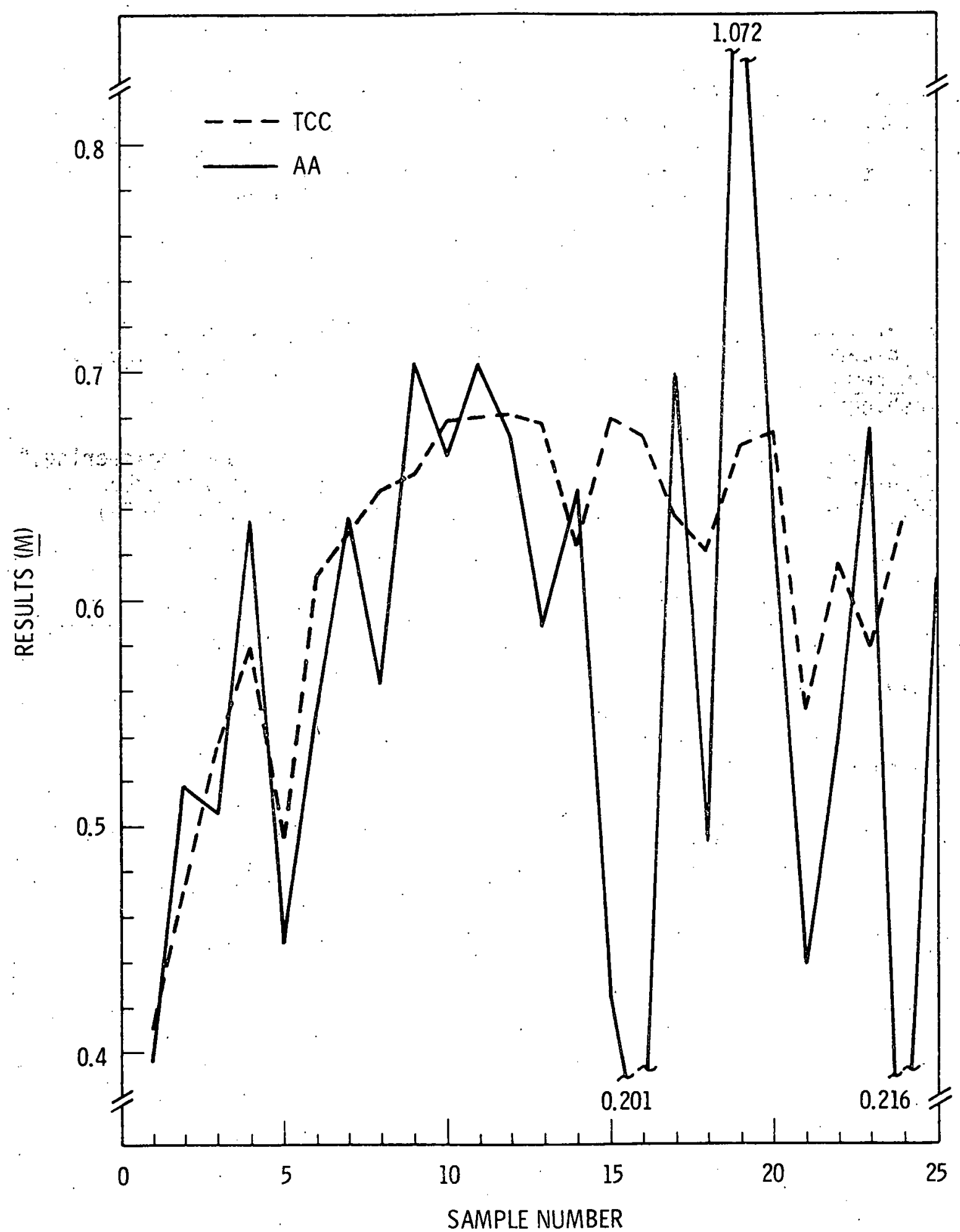

FIGURE 1 


\section{ACKNOWLEDGMENTS}

I wish to thank all the shift technologists of the 222-S Analytical Laboratory who contributed to the long-term study by analyzing the many samples involved. Thanks are also due A. H. Case and W. W. Schulz for. their editorial assistance, and also E. Y. Wagenaar and B. S. Snyder for their secretarial assistance in preparing this document.

\section{REFERENCES}

1. W. W. Schulz and M. J. Kupfer, "Solidification and Storage of Hanford's High-Level Radioactive Liquid Wastes," in High-Level Radioactive Waste Management, M. H. Campbell, Ed., American Chemical Society, Washington, D. C. (1976), pp. 54-71.

2. G. L. Richardson and W. W. Schulz, "Process Chemistry and Engineering," Chapter IV of Waste Management Technical Manual, J. S. Buckingham, Ed., ISO-100 DEL, Isochem, Inc., Richland, Washington (July 1966).

3. M. Kritz, Sklar a Keramik 6, 140 (1956).

4. F. J. Welcher, The Analytical Uses of Ethylenediaminetetraacetic Acid,

D. Van Nostrand Co., Inc., Princeton, New Jersey (1958), p. 53.

5. Ibid., p. 248.

6. H. A. Flaschka, EDTA Titrations, Pergamon Press, New York, New York, (1959). 
UNCLASSIFIED

ARH-ST -138

13

APPENDIX A

PROCEDURE FOR DETERMINATION OF TOTAL COMPLEXABLE CATIONS BY CHELOMETRIC TITRATION

Procedure

1. Pipet the required sample aliquot: into a prerinsed $15 \mathrm{ml}$ vial containing $210 \mathrm{ml}$ of deionized water and a glasscovered stir bar.

2. Check pH. If necessary, add $0.1 \mathrm{M} \mathrm{NaOH}$ or $\mathrm{HNO}_{3}$ dropwise untiT the $\mathrm{pH}$ is between 1 and 3.

3. While stirring, pipet exactly $1000 \mu 1$ of standard $0.1000 \mathrm{M}$ EDTA solution into the vial. Record exact concentration used.

4. Continue stirring and add ul $\mathrm{ml}$ of pyridine.

\section{Comment}

1a. Sample size should contain 20.05 to $0.08 \mathrm{millimole}$ of compl exable metal ions.

1b. Radiation hazard exists with hot samples. Check radiation readings and use appropriate shielding as necessary.

2a. This step may be omitted on routine B-Plant feed samples known to be acid $(0.5-1.5$ $\mathrm{M} \mathrm{H}^{+}$). Caustic samples should not be run without preliminary acidification.

3a. Solution will turn light yellow if iron is present.

4a. If a precipitate forms, either there was too much sample or it contained a large amount of 1 chromium (III) or some other. noncomplexable cation. Check the estimated metal content of the sample and rerun with a smal ler sample size.

4b. The pH should now be between 6 and 7.

5. Add 2 drops of $0.1 \%$ pyrocatechol $5 \mathrm{a}$. Solution should now be an violet indicator. intense yellow. 


\section{Procedure}

6. Before titrating sample, expel to waste a few drops of titrant (Standard $0.1000 \mathrm{M}$ copper) from the del ivery buret and reset the manostat to 0 . Rinse tip of buret with deionized water.

7. Lower tip of delivery buret carefully into the solution.

8. Titrate with the standard copper solution until a definite.blue-green color persists for more than 5 seconds.
Comment

6a. This is to take up any slack in the buret piston drive and to discard the titrant from the tip of the buret which may be contaminated or concentrated.

6b. Be sure buret is filled with titrant.

7a. Use care not to break the tip.

8a. Flashes of blue will occur as titrant is added and will be more persistent as the end point is approached.

8b. Solutions containing a high percentage of iron will slowly turn from yellow to green as the titration progresses. This is normal and should not be taken as the end point. 
APPENDIX B

PREPARATION OF THE SYNTHETIC 33-1 STANDARD

\section{Procedure}

1. Weigh $5.4 \mathrm{~g}$ of $\mathrm{Al}$ wire to $0.0001 \mathrm{~g}$ and dissolve in $100 \mathrm{ml}$ of $5 \mathrm{M} \mathrm{NaOH}$.

2. Weigh $8.7 \mathrm{~g}$ of reagent grade $\mathrm{MnO}_{2}$ to $0.0001 \mathrm{~g}$ and $\mathrm{place}$ in glass beaker. Add $30 \% \mathrm{H}_{2} \mathrm{O}_{2}$ slowly dropwise until mostly dissolved, then add a minimum of $12 \mathrm{M} \mathrm{HCl}$ to complete the dissolution. Solution must be boiled to expel the oxygen generated. Save this solution for Step 6 .

3. When $\mathrm{Al}$ is completely dissolved in the caustic, add a teflon stir bar. Stir gently and slowly add $170 \mathrm{ml}$ of concentrated $(15.6 \mathrm{M}) \mathrm{HNO}_{3}$, about $10 \mathrm{ml}$ at a time.

4. Weigh $1.18 \mathrm{~g}$ of $\mathrm{Ni}$ wire and $11.7 \mathrm{~g}$ of $\mathrm{Fe}$ wire to $0.0001 \mathrm{~g}$ and add to the solution in Step 3 , heating if necessary.

5. Add the following reagents to a $1000 \mathrm{ml}$ volumetric flask:

$$
\begin{aligned}
& 110.0 \mathrm{~g} \mathrm{NaNO} \\
& 9.4 \mathrm{~g} \mathrm{Ca}\left(\mathrm{NO}_{3}\right)_{2} \cdot 4 \mathrm{H}_{2} \mathrm{O} \\
& 1.0 \mathrm{~g} \mathrm{Mg}\left(\mathrm{NO}_{3}\right)_{2} \cdot 6 \mathrm{H}_{2} \mathrm{O} \\
& 0.6 \mathrm{~g} \mathrm{Sr}\left(\mathrm{NO}_{3}\right)_{2} \\
& 0.5 \mathrm{~g} \mathrm{KNO}_{3}
\end{aligned}
$$

6. Transfer the solution of $M n$ from Step 2 quantitatively to the flask. When the metals are completely dissolved, transfer the solution from Step 4, also quantitatively. Swirl gently to dissolve the nitrate salts.
Comment

1a. A11 metals used should be at least $99.5 \%$ pure.

3a. A thick precipitate of $\mathrm{Al}(\mathrm{OH})_{3}$ will form, but should redissolve after all the acid is added.

3b. Solution should now be 4-5 $\mathrm{M} \mathrm{H}^{+}$.

5a. These reagents may be weighed to $0.01 \mathrm{~g}$, as the concentrations these ions do not have to be exact. 
ARH-ST-138

APPENDIX B (contd)

Procedure

7. Pipet $3.000 \mathrm{ml}$ of each of the following stock standards to the solution in the flask:

$$
\begin{aligned}
& 1.00 \mathrm{M} \mathrm{Co}^{2^{+}} \\
& 1.00 \frac{\mathrm{M}}{\mathrm{Cr}^{3+}} \\
& 1.00 \mathrm{M} \mathrm{La}^{3^{+}} \\
& 1.00 \mathrm{M} \mathrm{Pb}^{{ }^{+}}
\end{aligned}
$$

8. Dilute to the mark with deionized water. Add a stir bar and stir thoroughly to mix the solution.

9. Calculate the concentration of each cation in the solution. Express the accurately determined concentrations ( $A 1, \mathrm{Fe}$, $\mathrm{Mn}, \mathrm{Ni}, \mathrm{Co}, \mathrm{Cr}, \mathrm{La}$ and $\mathrm{Pb}$ ) to four (4) places beyond the decimal point.

10. Calculate the total complexable cation content (TCC) as the sum of the eight cations listed in the above step. An example follows:
Comment

7a. The stock standards may be prepared by weighing out sufficient nitrate salt to make $100 \mathrm{ml}$ of solution. The amounts are (a)1 weighings to $.0001 \mathrm{~g}$ ):

$$
\begin{array}{ll}
29.1 & \mathrm{~g} \mathrm{Co}\left(\mathrm{NO}_{3}\right)_{2} \cdot 6 \mathrm{H}_{2} \mathrm{O} \\
40.0 \mathrm{~g} \mathrm{Cr}\left(\mathrm{NO}_{3}\right)_{3} \cdot 9 \mathrm{H}_{2} \mathrm{O} \\
43.3 \mathrm{~g} \mathrm{La}\left(\mathrm{NO}_{3}\right)_{3} \cdot 6 \mathrm{H}_{2} \mathrm{O} \\
33.1 \mathrm{~g} \mathrm{~Pb}\left(\mathrm{NO}_{3}\right)_{2}
\end{array}
$$

7b. It is understood that the above nitrate salts are normally not acceptable as primary standards. In this case, however, the final concentration of these metals is under 3 percent of the total cation concentration. Relatively large errors in these ions $(\sim 10 \%)$ can then be tolerated without a significant effect on the overall complexable cation content.
$\begin{array}{lll}\mathrm{Na}^{+} & 1.8 \mathrm{M} & * \mathrm{Mn}^{2} 2^{+} \\ \mathrm{H}^{+} & 0.76 & \mathrm{Ca}^{2} \\ \mathrm{Al}^{3}{ }^{+} & 0.2137 & * \mathrm{Nj}^{2}{ }^{+} \\ \mathrm{AFe}^{3} & 0.2001 & \mathrm{~K}^{+}\end{array}$
0.1072 M
0.04
0.0231
0.005
$\mathrm{Mg}^{2}{ }^{+}$
$\mathrm{CO}^{2}{ }^{+}$
$\mathrm{Cr}^{3}{ }^{+}$
$* \mathrm{La}^{3}$
$0.004 \quad 11 * \mathrm{~Pb}^{3}+$
$0.0028 \mathrm{M}$
$0.0030^{-} \mathrm{Sr}^{+} \quad 0.003$
0.0029
0.0030
${ }^{*}$ TCC $=0.5558 \mathrm{M}$ 


\section{DISTRIBUTION}

\section{Number of Copies}

U. S. Energy Research and Development Administration, Richland Operations Office

0. J. Elgert (2)

R. E. Gerton

U. S. Energy Research and Development Administration, Technical Information Center; Oak Ridge, TN

Atlantic Richfield Hanford Company

J. E. Atterberry

D. G. Blevins

J. S. Buckingham

G. Burch

A. H. Case

C. A. Colvin

R. N. Diebel

D. A. Dodd

J. E. Gilmer

L. M. Grey

R. D. Hammond

C. S. Homi

C. B. Honaker

S. T. Hurlbut

K. Iwatate

J. R. Jewett

S. J. Johnson

F. M. Jungfleisch

A. D. King

T. A. Lane

R. A. Latsch

T. W. Lutton

R. Maffeo

P. A. Meyer

B. H. Nicholson (15)

M. E. Palmer

D. A. Puryear

J. T. Rivera

W. H. Sant

A. E. Schilling
V. L. Schuelein

W. W. Schulz

E. Sherman

M. J. Smith

F. J. Sobeck

R. W. Spencer

C. P. Sutter

T. M. Tanner

L. H. Taylor

D. L. Uebelacker

J. E. Walsh

M. R. Whiting Document Services (3)

Extras (10) 